\title{
Revisiting Japanese Studies in Southeast Asia
}

\author{
Karl Ian Uy Cheng Chua
}

$凶$ kchengchua@gmail.com

\begin{abstract}
The purpose of this paper is to look at the development history and the current state of Japanese studies in Southeast Asia. The paper presents a number of stumbling blocks of various institutions in Southeast Asia, such as language issues and funding. The study ends with possible suggestions as well as solutions towards success in this area.
\end{abstract}

Keywords 日本研究(Japanese Studies), 東南アジア(Southeast Asia), 地域研究 (Area Studies) 
Japanese studies in Southeast Asia can be separated into two periods, pre-war and post-war. The pre-war educational engagements of Japan to Southeast Asia vary depending on the country's political relationship. Most of the Southeast Asian countries had trade relationships with Japan since the 16th Century. Siam recording the first red seal ships (朱印船) around 1604, and a formal embassy in Japan in 1621, the rest of Southeast Asia would only engage in active trade from the 17th Century without the establishment of a formal embassy. Aside from trade, this began educational relationships through the informal and unofficial study of Japanese language and culture.

The official beginnings of Japanese Studies in Southeast Asia happened during the advent to the Pacific War when Japan was at the height of its modernization project under the Meiji Government and was attempting to convince the other Asian countries to come under the Greater East Asia Co-Prosperity Sphere where various National Universities were asked to open courses for Japanese language to local students. However, the war overtook this measure which then integrated the programs under the propaganda structure of the Japanese colonial government.

It was only during the post-war period with the restoration of diplomatic relations that Japanese Studies began to take root. One of the earliest would be Thailand in 1952, Cambodia in 1953, followed by Myanmar in 1954, Laos in 1955, the Philippines in 1956, Malaysia in 1957, Indonesia in 1958, Singapore in 1966, Vietnam in 1973 and Brunei in 1984.

This post-war relations allowed Japan to re-start its pre-war activities with the Southeast Asian countries through the re-development or re-establishment of Japanese Studies departments in national universities in the various countries, and is understood by most members as the "official beginnings" of Japanese Studies in Southeast Asia.

\section{The State of Japanese Studies in Southeast Asia}

One of the earliest studies was the conference proceedings of the fourth Leverhulme Conference in 10-15 March 1969. (King 1969) The conference was held roughly 25 years after the end of World War II and barely 20 years after the restoration of diplomatic relations in Southeast Asia. Despite the existence of Japanese Studies programs, there has been domestic indifference and anti-Japanese prejudice within Southeast Asia. Western and Japanese delegates of the conference with older histories of the establishment of Japanese Studies emphasized the importance of 
Japanese Studies based on examples of their own institutions, but confused the Southeast Asian delegates since the contexts in their countries were far different from that of the West and Japan. This was compounded by the fact that this period developed Southeast Asian Nationalist scholars who were suspicious of the West and were ambivalent to the Japanese.

It took about 20 years before more publications on the issue came about through the journal『世界の日本研究』(Japanese Studies Around the World) by the International Research Center for Japanese Studies or Nichibunken which began its first issue on 10 December 1990 which as the title of the journal suggests, seeks to introduce Japanese Studies institutions throughout the world. The first few issues focused on Europe and the United States, where Japanese Studies have older traditions. The first Asian countries to be features were Taiwan and India by the second issue, and Southeast Asia was featured by the fourth issue by dealing with individual countries, beginning with the Philippines through Josefa M. Saniel's "The Study of Japan in the Philippines: Focus on the University of the Philippines" in 1992. (Saniel 1992). This was followed by a piece by I Ketut Surajaya entitled「インドネシアにおける日本研究の現状と将来」 in 1993. (Surajaya 1993) By the next year, Stephen Leong's "Japan Studies and Japanese Studies in Malaysia" (Leong 1994) and Seah Chee Meow's "Japanese Studies Department at the National University of Singapore: Redefining its Relevance and Viability" (Meow 1994) were published.

Aside from sharing the histories of how each country established Japanese Studies departments or programs, with their beginnings in Japanese Language education and developed into the study of Japan. Furthermore, there were arguments regarding the labelling of the area study between "Japanese Studies" or "Japan Studies" where the difference "Japanese Studies" follows the European tradition of non-Japanese scholars who study Japan as an ancient or classical, historical culture of the East vis-à-vis to Chinese studies. (Saniel 1992) (Meow 1994) (Leong 1994) On the other hand, “Japan Studies" began in the United States in training centers established during World War II to teach Japanese language, history and culture which later evolves into a study of Modern Japan. (Saniel 1992) (Meow 1994) (Leong 1994) Saniel adds a third term "the study of Japan" which does not preclude knowledge of the Japanese language, and deals with topics that partly cover Japan. (Saniel 1992)

An edited volume by Nichibunken entitled「日本研究」 came out with a special issue on 1994 with the theme「世界の日本研究一歴史と現状」with a reprints of the Philippine and Indonesian articles [ジョセファー・M・サニエル 1994](イ・ケトット・ス ラジャヤ 1994) and an article by 疋田正博 on the state of Thai Japanese Studies with 
the piece「タイにおける日本研究」（疋田正博 1994)

There would be a large gap in the publications by Nichibunken on Southeast Asia, until 2013 with special issue on New Trends in Japanese Studies featuring four articles on three countries. This included a piece by 岩井茂樹 entitled「タイにおける日本研究 の現状と課題」（岩井茂樹 2013），Ho Hoang Hoa’s「べトナムにおける日本研究」(Hoa 2013), and two pieces on the Philippines on "A History of the Japanese Studies Program at the Ateneo de Manila University" (Japanese Studies Program 2013) and Dennis D. Trinidad's "Japanese Studies at De La Salle University." (Trinidad 2013) The series of articles focused on the state of recent Japanese studies in Southeast Asia moving beyond previous discussions on Japanese Studies, Japan Studies and the Study of Japan.

\section{Issues on Japanese Studies in Southeast Asia}

The earliest articles which recognized issues on Japanese Studies in Southeast Asia was by Surichai Wun'gaeo's “Japanese Studies in Southeast Asia: Problematic Trends and Challenges Ahead." (Wun'Gaeo 1996) which featured the following key features (1) that Japanese studies was entering a booming period in higher institutions due to the growing demand in learning from Japan's development experience, (2) Southeast Asia was conducive for growth in Japanese studies due to external funding received from Japan, as well as individual governmental policies, (3) strength and focus on language-based education. (Wun'Gaeo 1996) Nonetheless, there were challenges such as (1) weak relationship between Japanese studies and social sciences, with the focus on Japanese language education, (2) interest in Japan lay on Japan's economic growth, relations, management, (3) an acceptance in the humanities of simplistic Nihonjin-ron ideologies. (Wun'Gaeo 1996)

It has been 20 years from Wun'Gaeo's article, and there is a need to revisit and review these points. In the Philippines, the Japanese Studies Program of the Ateneo de Manila University is one of the oldest programs in Southeast Asia which began in 1967 offering Japanese language classes in the tertiary level, followed by a minor in Japanese Studies in 1990, and a Master's in Japanese Studies in 1998. The first director was Hisatake Masao (Economics) in 1966. This was followed by the University of Indonesia which opened its Department of Japanese Studies in 1972 with an undergraduate program on Japanology. Singapore would establish its Department of 
Japanese Studies in 1981 initially as an undergraduate program under Kumekawa Mitsuki (Literature), followed by a Master's and Doctorate program in 1990s. Under the Royal Patronage Princess Mahachakri Sirindhorn that the Institute of Japanese Studies within Thammasat University was established in 1984. In Vietnam, while an undergraduate program in Japanese language was established in the Hanoi Foreign Trade University in 1961, a Japanese Studies Center was opened in the Vietnam Academy of Social Sciences in 1993. The Vietnam National University would then open a Master's program in 2000 in the Hanoi campus, and in 2008 in the Ho Chi Minh Campus. There are far older institutions, such as the University of the Philippines which began with individual visiting faculties from Japan in 1920, and teaching of Japanese language under the Department of Linguistics and Oriental Languages in 1960s. However, this paper focuses primarily on institutions which were established with the purpose of focusing primarily on Japanese Studies.

What is observable with these institutions is that all are initially supported by the Japan Foundation through the sending of directors, and visiting faculty, and library support. To give you an example here is the list of directors for the Japanese Studies Program of the Ateneo de Manila University:

\begin{tabular}{|c|c|c|}
\hline Name & Research Field & Period \\
\hline 1. Hisatake. Masao & Economics & Dec. 1966-June 1967 \\
\hline 2. Tsuru. Haruo & Education & $\begin{array}{l}\text { July 1967-Feb. } 1969 \\
\text { June 1971- Dec. } 1971\end{array}$ \\
\hline 3. Satō, Nobuyuki & Anthropology & Mar. 1969- July 1970 \\
\hline 4. Ichinose. Tomoji & Management & July 1970- June 1971 \\
\hline 5. Hoshino, Akira & Psychology & Dec. 1971- June 1972 \\
\hline 6. Kasai, Minoru & History of Social Thoughts & June 1972-Oct. 1973 \\
\hline 7. Furuya. Yasuo & Theology & Oct. 1973-Mar. 1975 \\
\hline 8. Hara, Kimi & Political Science & Apr. 1975-May 1976 \\
\hline 9. Fujita. Tadashi & Economics & May 1976-Mar. 1977 \\
\hline 10. Hashimoto, Tetsuichi & Political Science & Mar. 1977-Apr. 1978 \\
\hline 11. *Fr. Nebres, Bienvenido & Dean, College of Arts and Science & Apr. 1978- Oct. 1980 \\
\hline 12. Fernandez, Doreen G. & English Literature & $\begin{array}{l}\text { Nov. 1. } 1980 \text {-Oct. } 31 . \\
1986\end{array}$ \\
\hline 13. *Fr. Bonoan. Raul & Dean. College of Arts and Sciences & Nov. 6. 1986-May 1987 \\
\hline 14. *Leovino Ma, Garcia & Dean, College of Arts and Sciences & June 1987-May 1989 \\
\hline 15. Yu-Jose, Lydia N. & International Relations & $\begin{array}{l}\text { June 1989-Mar. } 1993 \\
\text { June 1995-Mar. } 1996\end{array}$ \\
\hline 16. Nagai, Hiroko (Acting director) & Anthropology & Mar. 1993-Mar. 1995 \\
\hline 17. Valiente. Tito G. (OIC) & M.A. Cand. In Anthropology & Apr. 1995-May 1995 \\
\hline 18. Rivera. Helen Y. (OIC) & M.A. in Japanese Studies & Apr. 16-June 16, 2001 \\
\hline
\end{tabular}




\begin{tabular}{|l|c|c|}
\multicolumn{1}{|c|}{ Name } & Research Field & Period \\
\hline 19. Tan, Rosalina P. & Economics & $\begin{array}{c}\text { Apr. 1996-Mar. 31. 2001 } \\
\text { June 17. 2001-Mar. 2004 }\end{array}$ \\
\hline 20. Yu-Jose, Lydia N. & & Apr. 2004-Mar. 2007 \\
\hline 21. Nagai, Hiroko & International Relations & Apr. 2007-April 2014 \\
\hline 22. Cheng Chua, Karl lan Uy (Acting Director) & Geography & June 2011-Mar. 2012 \\
\hline 23. Cheng Chua, Karl lan Uy & Social Sciences & April 2014 - Present \\
\hline
\end{tabular}

However, support is not limited to Japan Foundation, as some national institutions would receive some form of support/subsidy from the national government, such as the patronage of Princess Srindhorn of Thailand, and "Look to the East" policy of Prime Minister Mahathir Mohamad of Malaysia. Furthermore, Singapore was able acquire other sources of funding such as Mitsui \& Co., Japan Chamber of Commerce of Singapore, Okinawa Prefectural Government, and Japan Securities.

Despite the support from various institutions to the development of Japanese Studies programs what can be observed is the steady move towards localization of the programs/departments in Southeast Asia. As observed in table above, for Ateneo de Manila University, localization began with the 11th Director, while other countries would have began earlier. Furthermore, the nature and development of each program was shaped by the directors of the said program.

Aside from the diversity of focus, there are various national associations, such as The Japanese Studies Association of Thailand (JSAT), the Malaysian Association of Japanese Studies (MAJAS), and the Japanese Studies Association of Indonesia (ASJI). The Philippines, Singapore and Vietnam does not yet have a national Japanese Studies organization, with the latter due to being interpreted as a "political organization" by the government. Countries with Japanese Studies Associations would have annual meetings, conferences, and publications, these are confined to the national languages, with occasional publications in Japanese or English. Thus making it difficult of fellow Southeast Asian scholars from reading each other's works.

Thus, the establishment of the Japanese Studies Association of Southeast Asia (JSA-ASEAN) under the vision of Terada Takashi, formerly from National University of Singapore, and currently with Doshisha University. The Japanese Studies Association in Southeast Asia (JSA-ASEAN) is a network among Japanese Studies specialists from Southeast Asia. It was set up in 2005 to serve as a catalyst in promoting Japanese studies in this region. It is the only organization with the aim of bringing together major Japanese studies specialists from various Southeast Asian countries with their counterparts from Japan and other countries. It is hoped that with the combined 
resources of Japanese Studies specialists in Southeast Asia, JSA-ASEAN will grow to become an important platform for the promotion of region-wide Japanese studies.

In order to stimulate interest in and encourage research, teaching, and scholarly networking in Japanese Studies both among Southeast Asian countries as well as globally, JSA-ASEAN organizes a biennial conference as the major platform for trans-disciplinary international exchange. The inaugural conference was hosted by Department of Japanese Studies, National University of Singapore in October 2006, in conjunction with the 25th anniversary celebration of the Department of Japanese Studies and to mark the 40th anniversary of diplomatic relations between Japan and Singapore. In October 2009, the second JSA-ASEAN conference was organized in Hanoi, Vietnam with funding from Japan Foundation and the Mitsui-NUS Endowment Fund to promote Japanese Studies in Southeast Asia. The host was the Vietnam Academy of Social Sciences. This was followed by conferences in Kuala Lumpur (Malaysia) in 2012 hosted by the University of Malaysia, Bangkok (Thailand) in 2014 hosted by Thamassat University and Cebu (Philippines) in 2016 hosted by Ateneo de Manila University, De La Salle University and the University of the Philippines. The forthcoming JSA-ASEAN conference in 2018 will be in Jakarta (Indonesia) and will be hosted by the University of Indonesia. With the various languages spoken in Southeast Asia, the official languages of the JSA-ASEAN Conference are English and Japanese. Despite this arrangement, it is still a struggle for members and attendees to communicate and collaborate as the language proficiencies, particularly academic level language proficiencies vary in Southeast Asia. Just to present an example, the English Language proficiency index in Asia is as follows:

\section{New Issues in Japanese Studies}

With the building of relationships between Southeast Asian institutions conducting Japanese Studies, one of the new issues was in which language do the members conduct their research in. The five member countries of JSA-ASEAN have different language proficiencies, with Indonesia functioning with Bahasa Indonesia, Malaysia with Bahasa Melayu, Chinese, Tamil, Philippines with Filipino and through mother-tongue education policies, include major Dialects, Singapore with Chinese, Malay, Tamil and English, Thailand with Thai, and Vietnam with Vietnamese. To further complicate the linguistic world of education, these countries also include their colonial languages, such as Dutch, French, Spanish, and English.

Thus the logical approach is to conduct research, and dialogue in English. However, 
according to the English Proficiency Index (EPI) of a private company, Europeiska Ferieskolan (EF), there is an inequality of English proficiencies throughout the world. The EPI Average of Asia in 2016 was 55.94 which can be categorized as "high."

EF EPI Average

55.94
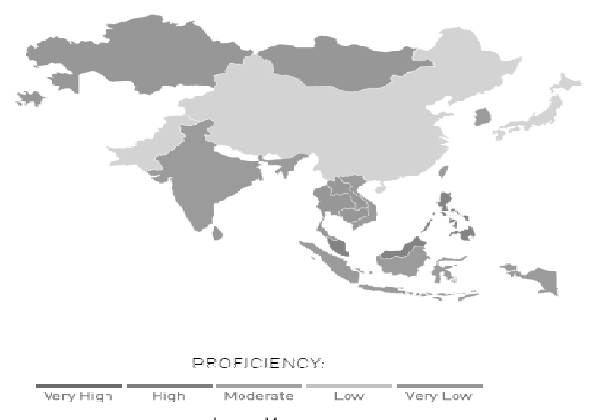

(http://www.ef.com/)

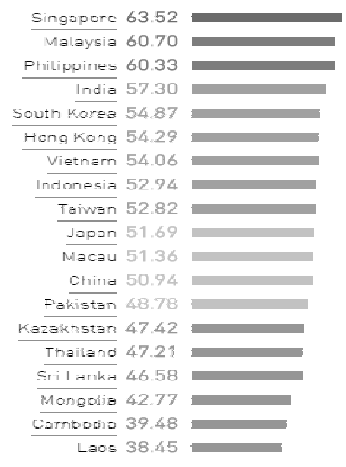

200038.45

This has dropped in 2017, with an average of 53.60. It is still within the "high" category, but from the data of the past two years, only Singapore is categorized as "very high," Malaysia and the Philippines as "high," Vietnam as "moderate," Indonesia dropped from "moderate" to "low" with Thailand who increased from a "very low" last year.

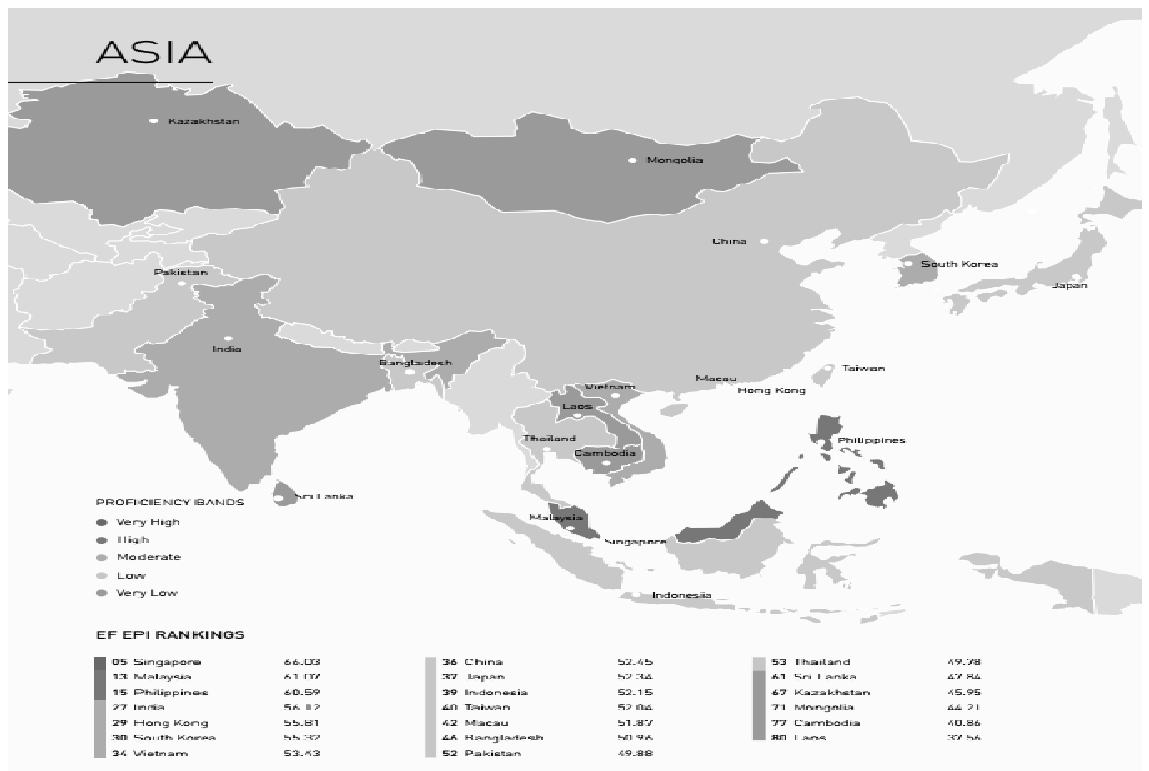

(http://www.ef.com/) 
What can be surmised from this, is the grave inequality of English proficiencies among the partners which unfairly benefits countries with high English proficiency if one is "forced" to write in English or to present their papers in English.

On the other hand, since Japanese studies requires a level of Japanese language proficiency, Japanese could be the language of choice. However, the Japanese language proficiency in Asia, there is also inequality.

\begin{tabular}{|c|c|c|c|c|c|c|c|c|c|c|c|c|c|c|}
\hline $\begin{array}{c}\text { インドネシア } \\
\text { Indonesia }\end{array}$ & R+k & Manado & 2 & 2 & 21 & 18 & 34 & 26 & 67 & 46 & 89 & 55 & 213 & 147 \\
\hline \multirow{3}{*}{$\begin{array}{l}\text { カンポジア } \\
\text { Cambodia }\end{array}$} & フフンメン & Phnom Penh & 60 & 57 & 192 & 179 & 313 & 291 & 270 & 262 & 138 & 126 & 973 & 915 \\
\hline & シメムリフップ & Stem Hoap & 1 & 0 & 12 & 9 & 29 & 27 & 52 & 47 & 30 & 26 & 124 & 109 \\
\hline & \multicolumn{2}{|l|}{ カンボリ゙フ計 Total } & 61 & 57 & 204 & 188 & 342 & 318 & 322 & 309 & 168 & 152 & 1,097 & 1,024 \\
\hline $\begin{array}{c}\text { シンガボール } \\
\text { Singapore }\end{array}$ & ンンガーールール & Singapore & 255 & 232 & 374 & 330 & 359 & 323 & 485 & 428 & 497 & 439 & 1,980 & 1,752 \\
\hline \multirow{3}{*}{$\begin{array}{c}\text { タ1 } \\
\text { Thailand }\end{array}$} & ハンコク & Banghok & 1,056 & 873 & 2,031 & 1,775 & 2,706 & 2,303 & 3.010 & 2,504 & 2,690 & 2,299 & 11,493 & 9,754 \\
\hline & チエンマイ & Chlang Mai & 37 & 34 & 100 & 85 & 214 & 188 & 409 & 366 & 342 & 301 & 1,102 & 974 \\
\hline & \multicolumn{2}{|l|}{$g$ 1 it Total } & 1,093 & 907 & 2,131 & 1,860 & 2,920 & 2,491 & 3,419 & 2,870 & 3,032 & 2,600 & 12,595 & 10,728 \\
\hline \multirow{4}{*}{$\begin{array}{l}\text { フィリビン } \\
\text { Philippines }\end{array}$} & マニラ & Manta & 108 & 93 & 258 & 232 & 441 & 391 & 1,520 & 1,382 & 1,333 & 1,167 & 3,660 & 3,265 \\
\hline & セフ & cotou & 5 & 3 & 24 & 18 & 55 & 47 & 129 & 117 & 147 & 132 & 360 & 317 \\
\hline & 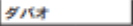 & Daveo & 4 & 3 & 20 & 20 & 52 & 50 & 232 & 210 & 314 & 271 & 622 & 554 \\
\hline & \multicolumn{2}{|l|}{ フィリビンIt Total } & 117 & 99 & 302 & 270 & 548 & 488 & 1,881 & 1,709 & 1,794 & 1,570 & 4,542 & 4,136 \\
\hline \multirow{4}{*}{$\begin{array}{l}\text { ヘトナム } \\
\text { Vietnam }\end{array}$} & ハノ & Hand & 933 & 766 & 3,006 & 2,596 & 5,217 & 4,525 & 3,639 & 3,004 & 1,823 & 1,462 & 14,618 & 12,352 \\
\hline & ホーチをン & Ho Ch Mrn & 704 & 556 & 2,434 & 2,079 & 4,104 & 3,578 & 4,340 & 3,693 & 3,798 & 3,238 & 15,380 & 13,144 \\
\hline & タナン & Da Nang & 135 & 122 & 547 & 472 & 752 & 676 & 1,035 & 905 & 707 & 604 & 3,176 & 2,780 \\
\hline & \multicolumn{2}{|l|}{ スト+ } & 1,772 & 1,444 & 5,987 & 5,146 & 10,073 & 8,779 & 9,014 & 7,603 & 6.328 & 5,304 & 33,174 & 28.276 \\
\hline \multirow{4}{*}{$\begin{array}{l}\text { マレーシア } \\
\text { Malaysia }\end{array}$} & フフラルンブール & Kuala Lumpur & 80 & 68 & 224 & 200 & 165 & 144 & 190 & 160 & 355 & 313 & 1,014 & 894 \\
\hline & メேン & Penang & 11 & 10 & 36 & 33 & 26 & 26 & 45 & 41 & 95 & 88 & 213 & 198 \\
\hline & イ标一 & lyoh & 2 & 2 & 8 & 7 & $\mathrm{~s}$ & 8 & 9 & 8 & 15 & 14 & 42 & 39 \\
\hline & \multicolumn{2}{|l|}{ マレーシブt Tokal } & 93 & 80 & 268 & 249 & 199 & 178 & 244 & 209 & 465 & 415 & 1,269 & 1,131 \\
\hline $\begin{array}{l}\text { ミャンマー } \\
\text { Myanmar }\end{array}$ & マンタレー & Mandalay & 135 & 98 & 264 & 197 & 450 & 342 & 659 & 464 & 1,004 & 624 & 2,513 & 1,725 \\
\hline 柬南アジア & \multicolumn{2}{|c|}{ It Southeast Asia Total } & 3.520 & 2,919 & 9.551 & 8,258 & 14,935 & 12,945 & 16,091 & 13,638 & 13,377 & n,159 & 57,483 & 48,919 \\
\hline
\end{tabular}

(http://www.jlpt.jp/statistics/pdf/2016_1_3.pdf)

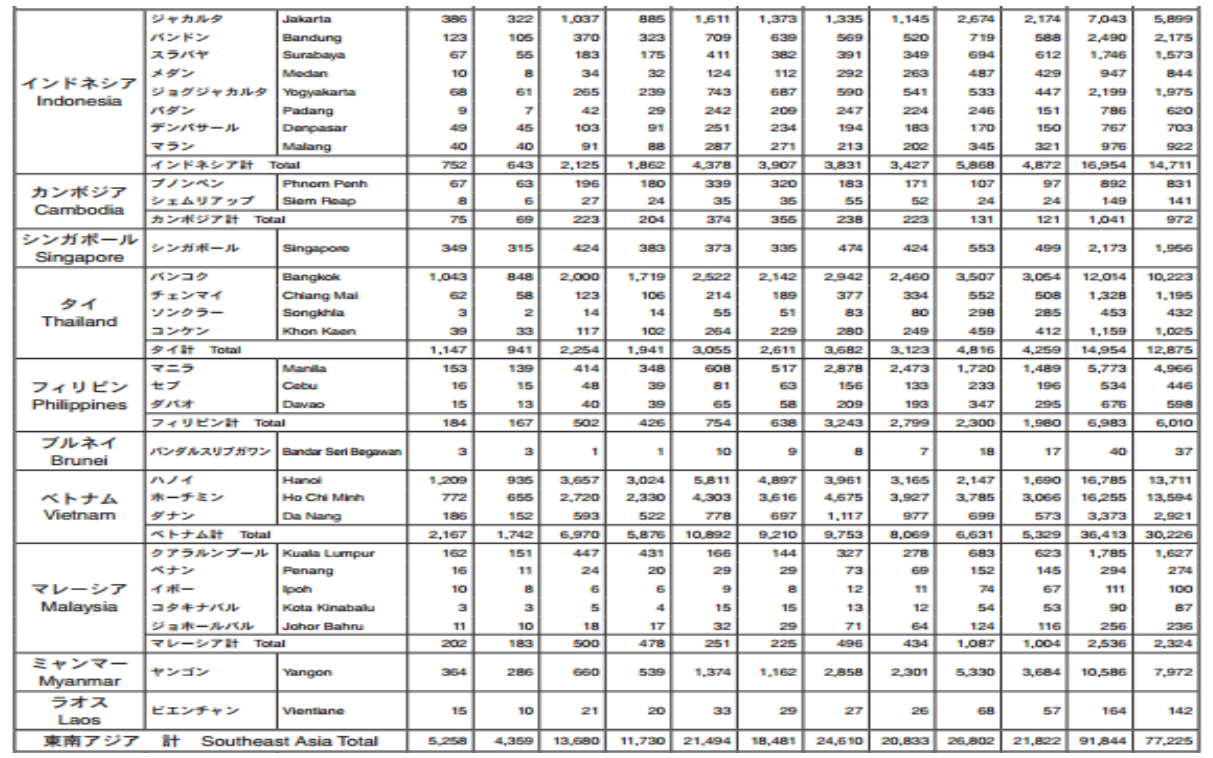

(http://www.jlpt.jp/statistics/pdf/2016_2_3.pdf) 


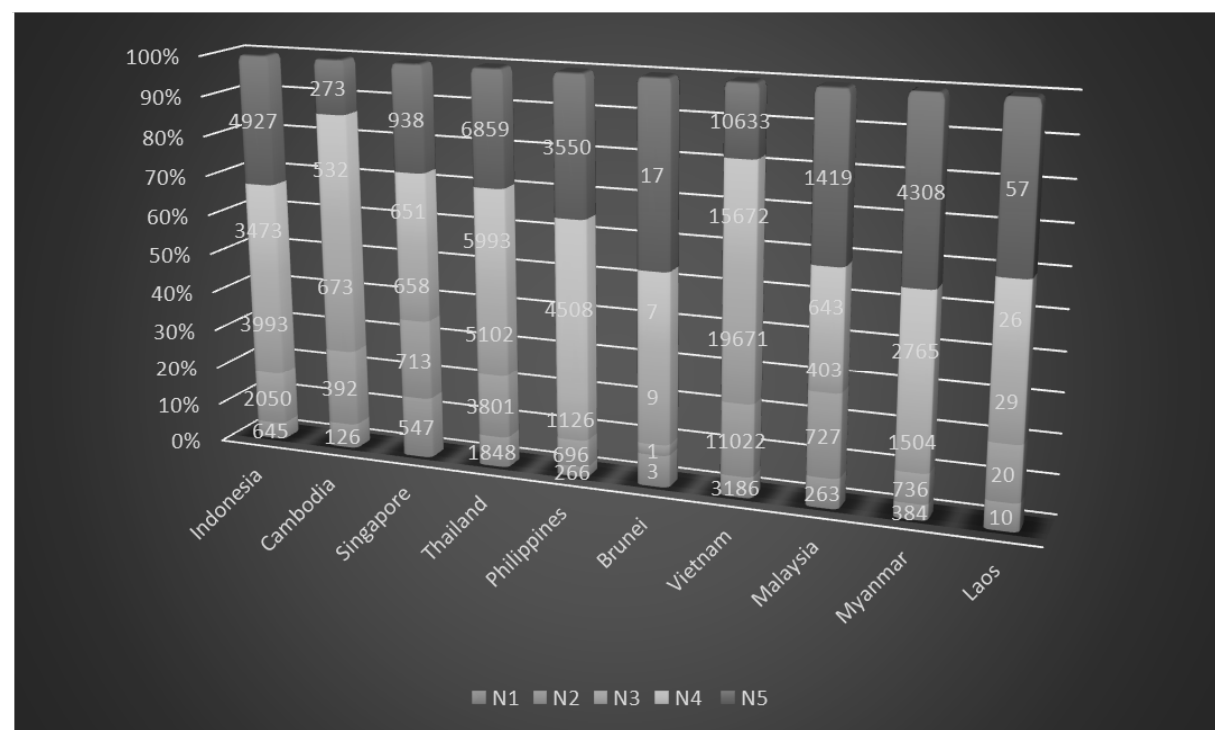

It is quite interesting that countries with the lowest English language proficiencies have the highest Japanese language proficiencies. While thus tilts the scale to benefit Indonesia, Vietnam and Thailand.

What this means is that the Southeast Asian Japanese studies scholars may hardly read each other due to the difficulties is collaborative research, as seen in the Graduate Thesis database which can be categorized into three categories: (1) fully downloadable such as that of National University of Singapore: http://scholarbank.nus. edu.sg/ (English), Vietnam Academy of Social Sciences: http://en.vass.gov.vn/noidung/ anpham/Pages/Default.aspx (Vietnamese), Vietnam National University, Hanoi: http:// repository.vnu.edu.vn/ (Vietnamese), Thammasat University: http://library.tu.ac.th/ (Thai), Chulalongkorn University: https://library.car.chula.ac.th/ (Thai); (2) Searchable, such as University of Malaya: http://www.diglib.um.edu.my/umtheses/\#sthash.ivTwEnTz.dpbs (Bahasa Malaysia/English), Ateneo de Manila University: http://bit.ly/2s6mFOO (English), De La Salle University: http://lib1000.dlsu.edu.ph/ (English), University of the Philippines, Diliman: http://ilib.upd.edu.ph/ (English/Filipino); and (3) Limited download, such as University of Indonesia: http://www.lib.ui.ac.id/\#horizontalTab2 (Bahasa Indonesia)

Observable from this is the academic traditions of each country which requires their students to write their graduate theses or dissertations in the academic language of each country, with two countries functioning on English, a third providing a choice in allowing English, and the rest has to be done in their academic language. What is 
noticeable is that none actually allowing their students to write in Japanese.

Currently, the JSA-ASEAN Steering Committee includes the following universities: National University of Singapore, University of Malaysia, Vietnam Academy of Social Sciences, Vietnam National University, Hanoi, Thamassat University, Chulalongkorn University, Ateneo de Manila University, University of the Philippines, Diliman, University of Indonesia, and Doshisha University. Due to the language restrictions of each country, the conference decided upon a bilingual approach, either in English or Japanese, which allows scholars from all the countries in Southeast Asia, which creates a space that allows for academic exchange among the participants in a language they are most comfortable in.

Aside from the multilateral engagements allowed by the JSA-ASEAN Conference, Japanese Studies scholars in Southeast Asia are limited to bilateral engagements, through their networks or transregional engagements, through larger Japanese Studies Conferences, such as this event, the Association for Asian Studies, the European Association for Japanese Studies, and the Japanese Studies Association of Australia. Although participation is also restricted due to large association fees, and travel costs.

The Japan Foundation was able to encourage more active interactions through the hosting of the Japan Foundation Summer Institute in Japan beginning on 2015 which is aimed to provide opportunities for young researchers and graduate students to improve their research methods and abilities, and build a trilateral network among researchers from Japan, the U.S., and Southeast Asia. It is currently on its third year.

This was paired with the Japan Foundation US - Southeast Asia - Japan Collaboration and Exchange Initiative which is designed to connect Japanese studies scholars from the U.S., Southeast Asia, and Japan in order to enhance their collective scholarship through collaborative projects and exchanges, as well as to advance Japanese Studies in these three regions. Projects will be based at U.S. institutions with strong existing or developing Japanese Studies programs, in order to share the wealth of Japanese Studies resources present in the U.S., and to establish and/or strengthen connections with individuals and institutions in Southeast Asia and Japan.

While such initiatives exist, these are not without their own "growing pains" to which institutions engaged in Japanese Studies in Southeast Asia are willing to try out. 


\section{Futures and Potentials}

To approach the issue of language, the Kyoto Review of Southeast Asia (Chachavalpongpun 2002) is an e-journal which is managed by the Center of Southeast Asian Studies of Kyoto University, which translates the short articles into 4 languages, English, Japanese, Thai, and Bahasa. Despite the fact that each article is 1500 words in English, it allows for an interaction with fellow scholars in Southeast Asia and encourages them to read each other.

A new movement is also being encouraged within Japanese Studies in Southeast Asia following Kuan-Hsing Chen's book "Asia as Method: Toward Deimperialization" (Chen 2010) which emphasizes the decolonization of academic research which seems to focus primarily on American or European traditions, and standards. This forgets that the contexts within the various countries in Southeast Asia are varied and contests the findings of their American or European counterparts. This movement does aim to displace or replace the long standing academic traditions of America or Europe, or even the academic traditions of Asian centers like East Asia. Rather, the emphasis of "Asia as a Method" is to present an alternative perspective to these central traditions.

Japanese Studies in Southeast Asia has potential to which needs to be explored and re-explored. The future remains promising if we in Southeast Asia maintain our vigilance understanding our strengths and weaknesses.

\section{参考文献}

Chachavalpongpun. Pavin.(2002) Kyoto Review of Southeast Asia. March. アクセス日：2017年12月1日. https://kyotoreview.org/.

Chen, Kuan-Hsing (2010) Asia as Method: Toward Deimperialization. USA: Duke Univesity Press.

HoangHoa, Ho (2013)「ベトナムにおける日本研究」(『世界の日本研究』第17号), pp.39-42. Hoanghoa, Ho (2013), 'Bettonamu ni okeru nihonkenkyu' Sekai no nihonkenkyu No.17. Nichibunken, pp.39-42.

Japanese Studies Program. Ateneo de Manila University (2013)「〈フィリピン〉A History of the Japanese Studies Program at Ateneo de Manila University」(『世界の日本研究』第17号), pp.19-30.

King. H. Frank (1969) 'The Development of Japanese Studies in Southeast Asia' Proceedings of the Fourth Leverhulme Conference. March 10-15, Hong Kong: Center of Asian Studies, University of Hong Kong.

Leong. Stephen (1994) 'Japan Studies and Japanese Studies in Malaysia' Japanese Studies Around the World 6. Nichibunken, pp.23-44.

Seah. Chee Meow (1994) 'Japanese Studies Department at the National University of Singapore: Redefining its Relevance and Viability' Japanese Studies Around the World 6. Nichibunken, pp.45-82.

Saniel. M. Josefa (1992) 'The Study of Japan in the Philippines: Focus on the University of the Philippines' 
Japanese Studies Around the World 4. Nichibunken, pp.1-78.

Surajaya. Ketutl(1993) ‘インドネシアにおける日本研究の現状と将来’ Japanese Studies Around the World 5. Nichibunken, pp.1-12.

Trinidad. D. Dennis (2013) 'Japanese Studies at De La Salle University' Japanese Studies Around the World 17. Nichibunken, pp.31-34.

Wun'Gaeo. Surichai (1996) 'Japanese Studies in Southeast Asia: Problematic Trends and Challenges Ahead' Kyoto Conference on Japanese Studies. Kyoto: Nichibunken, pp.169-178.

イ・ケトット・スラジャヤ(1994)「インドネシアにおける日本研究の現状と将来」(『日本研究』第10号). pp.49-56. Yi Ketoto, Surajya(1994) 'Indonesia ni okeru nihonkenkyu no kenjyo to shorai' Nihonkenkyu No.10, pp.49-56.

ジョセファー・M・サニエル (1994)「フィリピンにおける日本研究一主にフィリピン大学(U.P.)に関して」(『日本研 究』第10号)，pp.39-42. Saniel, Josefa M. (1994) 'Philippines ni okeru nihonkenkyu: Omoni Philippinesdaigaku ni kaneshite' Nihonkenkyu No.10, pp.39-42.

岩井茂樹(2013)「タイにおける日本研究の現状と課題」『世界の日本研究』第17号), pp.10-18. Iwai, Shigeki(2013) 'Thai ni okeru nihonkenkyu no genjyo to kadai' Sekai no nihonkenkyu No.17. pp.10-18.

疋田正博 (1994)「タイにおける日本研究」『世界の日本研究』第17号)。pp.43-47. Hikita, Masahiro (1994) 'Thai ni okeru nihonkenkyu' Sekai no nihonkenkyu No.17. pp.43-47.

荘啓宏 Karl lan Uy CHENG CHUA

(フィリピン)アテネオ・デ・マニラ大学日本研究学科長。歴史研究科。日本近現代史、览童文 学、大衆文化論。「想起を介した忘却一日比におけるアジア太平洋戦争の碑と観光」『歴史評論』 808号. 2017.8). "Boy meets world: the worldview of Shonen kurabu in the 1930s" Japan Forum Vol. 28. No. 1. 2016, pp.74-98) など。 
